\title{
The situational judgement test: a student's worst nightmare
}

This article was published in the following Dove Press journal:

Advances in Medical Education and Practice

5 October 2015

Number of times this article has been viewed

\author{
Muhammad Najim \\ Riham Rabee \\ Yusuf Sherwani \\ Maroof Ahmed \\ Muhammad Ashraf \\ Osama Al-jibury \\ Rula Najim \\ Imperial College London, South \\ Kensington, London, UK
}

Correspondence: Muhammad Najim Imperial College London, Exhibition Road, South Kensington, SW7 2AZ London, UK Email mnI409@imperial.ac.uk

\section{Dear editor}

The expert opinion by Singagireson et al $^{1}$ questioning the fairness of the Situational Judgement Test (SJT) is a fascinating insight and has brought to light a pertinent issue regarding job allocation for junior doctors.

The 2010 Improving Selection to the Foundation Programme: Appendix D FY1 Job Analysis report ${ }^{2}$ introduced a two-fold system in which newly graduated doctors are allocated jobs based solely on their educational performance measure (EPM) and SJT score. The EPM reflects the graduate's medical school performance based on their rank within their year group, as well as any other degrees and publications they have. The remaining $50 \%$ of a graduate's FY1 job allocation is based on the SJT.

An important issue has been raised by Singagireson et al, ${ }^{1}$ whereby $5-6$ years of hard work for a medical student has been put at jeopardy by a single, 2-hour test. Singagireson et $\mathrm{al}^{1}$ conclude that the SJT "is vital to ensure that the rank of a student is more reflective of their abilities to be a safe and competent junior doctor". A recent study has shown that judgement in SJTs, however, is not actually "situational"3 and that SJTs often fail to test the professional attributes that they are intended to assess.

The SJT intends to examine nine domains: 1) coping with pressure, 2) working effectively as part of a team, 3) organization and planning, 4) effective communication, 5) learning and professional development, 6) self-awareness and insight, 7) patient focus, 8) problem solving and decision making, and 9) commitment to professionalism. ${ }^{2}$ However, the authors cannot comprehend how the written SJT fairly and accurately tests these attributes.

It may be argued that current medical school examinations do not sufficiently assess the above professional attributes. However, from General Certificate of Secondary Education (GCSE) exams to medical school finals, junior doctors go through a grueling 9 years of back-to-back examinations, making them the UK's most academically assessed students. We believe that they should not be made to sit another examination demonstrating the professional attributes of an ideal doctor when they are yet to have any experience working as clinicians. The art of medicine is a lifelong learning process, and students are now spending their final year of medical school revising in libraries for the SJT, rather than being present on the wards getting that vital patient contact before starting work as a junior doctor.

Singagireson et $\mathrm{al}^{1} \mathrm{do}$, however, make a valid point about the lack of standardization when assessing students ranked "middle" at the UK's best medical school, who 
receive the same EPM points as students ranked middle at the UK's worst medical school, when surely the former group would be academically superior. Unfortunately, the SJT certainly does not solve this problem, as higher performing students from higher performing medical schools do not perform better in the SJT; ${ }^{4}$ therefore, the SJT only further disadvantages the top students from entering the top universities.

This situation has led many medical professionals to believe that the SJT may have been introduced merely to ensure that the country's brightest junior doctors are spread across the country, rather than allowing them all to enter the UK's most competitive deaneries, particularly in London. How can anyone defend a test that is being used as a tool within the UK National Health Service (NHS) to prevent the top applicants from securing the top jobs?

The question of how to allocate jobs to junior doctors still remains unanswered. We believe that the answer can be found by examining the traditional practice the rest of the rational world uses: interviews.

\section{Disclosure}

The authors report no conflicts of interest in this communication.

\section{References}

1. Singagireson S, Ramjeeawon N, Ravindra S, Shah N, Singh B. Is it fair for a junior doctor's deanery to be largely based on one test: a student's perspective. Adv Med Educ Pract. 2015;6:499-500.

2. Medical Schools Council. Improving Selection to the Foundation Programme: Appendix D. FY1 Job Analysis. London: Medical Schools Council; 2010. Available from: http://www.isfp.org.uk/AboutISFP/ Documents/Appendix_D_-_FY1_Job_Analysis.pdf. Accessed: August 242015 .

3. Krumm S, Lievens F, Hüffmeier J, Lipnevich AA, Bendels H, Hertel G. How "situational" is judgment in situational judgment tests? $J$ Appl Psychol. 2015;100(2):399-416.

4. Simon E, Walsh K, Paterson-Brown F, Cahill D. Does a high ranking mean success in the Situational Judgement Test? Clin Teach. 2015;12(1):42-45.

Dove Medical Press encourages responsible, free and frank academic debate. The content of the Advances in Medical Education and Practice 'letters to the editor' section does not necessarily represent the views of Dove Medical Press, its officers, agents, employees, related entities or the Advances in Medical Education and Practice editors. While all reasonable steps have been taken to confirm the content of each letter, Dove Medical Press accepts no liability in respect of the content of any letter, nor is it responsible for the content and accuracy of any letter to the editor.

Advances in Medical Education and Practice

\section{Dovepress}

\section{Publish your work in this journal}

Advances in Medical Education and Practice is an international, peerreviewed, open access journal that aims to present and publish research on Medical Education covering medical, dental, nursing and allied health care professional education. The journal covers undergraduate education, postgraduate training and continuing medical education including emerging trends and innovative models linking education, research, and health care services. The manuscript management system is completely online and includes a very quick and fair peer-review system. Visit http://www.dovepress.com/testimonials.php to read real quotes from published authors. 